\title{
The European Union, Conflict Management, and the Normative Illusion
}

Nuno Pereira de Magalhães

Professor na Universidade IE em Madrid e Investigador do IPRI-NOVA. Especializou-se em Relações Internacionais nas Universidades de Cambridge, Columbia e Harvard.

\begin{abstract}
The European Union (EU) has recently become the most active conflict manager, currently deploying more operations than any other organisation. There has been a total of 13 operations of military nature from 2003 to 2019, deployed in Europe and in Africa. The discourse at the level of the European Union emphasizes not only the security of its members but also the importance of humanitarian norms. Do these norms drive the deployment of EU's military operations? There is literature that recognizes the relevance of norms, suggesting that these factors may indirectly or even directly have a driving impact. On the contrary, I suggest that there is no normative driving impact. To be precise, I argue that power distribution and exposure to conflicts are the fundamental conditions driving the deployment of military operations by the EU.
\end{abstract}

Keywords: European Union; conflict management; United Nations; military operations.

\section{Resumo \\ A União Europeia, Gestão de Conflitos e a Ilusão Normativa}

A União Europeia (UE) tornou-se recentemente no mais ativo ator de gestão de conflitos, mantendo mais operações do que qualquer outra organização. Houve um total de 13 operações de natureza militar entre 2003 e 2019, implementadas na Europa e África. A retórica ao nível da UE enfatiza não apenas a segurança dos seus membros mas também a importância de normas humanitárias. Será que essas normas têm um efeito impulsionador no lançamento das operações militares da UE? Existe literatura académica que reconhece a relevância das normas, sugerindo que esses fatores têm um impacto impulsionador. Pelo contrário, eu sugiro que a distribuição de poder e a exposição aos efeitos dos conflitos são as condições fundamentais que guiam o lançamento das operações militares da UE. 


\section{Introduction}

The European Union (EU) became a military conflict manager in 2003, deploying its military resources in order to promote the decrease of violence in foreign disputes. From that year to the present, the EU deployed 13 conflict management operations of military nature in the Europe and in Africa, from a total of 35 operations (EEAS 2020). The first military mission was Operation Concordia deployed in the Former Yugoslav Republic of Macedonia (FYROM) - current North Macedonia - in 2003 and the last one was Operation EU Training Mission (EUTM) RCA launched in the Central African Republic (CAR) in 2016. The launching of EU's military missions is obviously related to security challenges - such as regional instability and terrorism - identified in the European Security Strategy (ESS) of 2003 and the 2016 EU Global Strategy - EUGS (European Union 2003; European Union 2016a). Nonetheless, EU discourse indicates that European conflict management is also driven by normative concerns of humanitarian nature. For instance, the Report on the Implementation of the ESS emphasizes that the "EU should continue to advance the agreement reached at the UN World Summit in 2005, that we hold a shared responsibility to protect populations from genocide, war crimes, ethnic cleansing and crimes against humanity" (European Union 2008, p. 12). This fits into EU's narrative of a "normative power" (Manners 2002) that promotes morally appropriate norms of humanitarian nature. The purpose of this article is precisely to examine the impact of normative concerns on EU's decisions, examining if those norms are sufficient and necessary conditions - drivers - behind conflict management: are humanitarian norms driving the deployment of EU's military operations?

There is literature influenced by liberalism and constructivism that suggest that the EU was driven, at least partially, by those norms. Some literature suggests an indirect impact of norms: humanitarian concerns of European publics had a driving impact on the deployment of military operations. According to this logic, failure to intervene in those conflicts could have had domestic political costs for European leaders (Pohl 2013a; 2013b; 2014), affecting their ability to get re-elected, thus making them consider that the military costs of launching operations of conflict management would be inferior to the potential political costs of idleness. Other literature goes further into normative causality and suggests a direct impact of norms: political leaders and officials were socialized within EU institutional structures up to the point that national and collective interests ended up merging in an internalized logic of European appropriateness. The structure of the Common Security and Defence Policy (CSDP) and its agents are "mutually constitutive" (Meyer and Strickmann 2011, p. 63). It would be a case of what Alastair Iain Johnston calls "a pro-norm behavior that is so deeply internalized as to be unquestioned, automatic, and taken for granted" (Johnston 2008, p. 16). In this sense, the deployment of EU's 
military operations would be influenced by what EU leaders and officials considered socially appropriate, shaped by the humanitarian role that the organization is expected to play.

Contrarily, I suggest that it is illusory to think that norms played a determinant role in driving the deployment of EU's military operations. Contrarily, what seems to drive the deployment of military operations are factors associated to security, namely power distribution and exposure to conflicts. To be precise, I suggest that the EU deployed military operations in order to promote spheres of influence in systemic spaces neglected by the United States (US) and to prevent negative externalities stemming from conflicts to which they were more exposed.

The following section presents my realist argument for the deployment of military operations of conflict management and the methods used to support it, as opposed to the normative hypothesis. The third section offers background information on EU's conflict management under the European Security and Defence Policy (ESDP) and the CSDP. The following two sections analyze the deployment of EU's military operations in Europe and in Africa as a function of power distribution and exposure to conflicts, demonstrating that all deployments were aimed at dealing with security goals that were shaped by those two factors, rather than by normative goals.

\section{Theoretical Framework}

The launching of military operations for normative reasons would be a joyful outcome for those of us who are touched by altruistic solidarity. This would open the door to endless possibilities of cooperation, exercised on the back of states socialized into patterns of humanitarianism rather than following a self-help process of competition where egoist interests prevail. Unfortunately, as much as one would like to conclude that the EU has deployed military operations in order to fulfil its normative aspirations of humanitarian nature, empirical evidence suggests otherwise.

Firstly, there is no correlation between shifts in support for EU's cooperation at military level and shifts in the preferences of electorates, in the sense that support has been consistently high from 1991 to the present and has not reflected variation at the level of military cooperation. For example, during the 1991-1997 period there was strong support from public opinion in the EU in regard to security cooperation, ranging from 65 percent in 1991 to 52 percent in 1997, reaching a peak of 78 percent support in 1994 (European Commission 2020a). If the domestic demand hypothesis was correct we should have witnessed EU's military operations being deployed in the mid-1990s rather than seeing the process of institutional-building kicking in during a period of less domestic support, a puzzling choice especially in the UK, 
with the majority of public being hostile or indifferent to the idea of defence cooperation - only 35 percent support in 1997 (European Commission 2020a).

Secondly, the literature offers examples of public opinion supporting the launching of conflict management operations, but it does not demonstrate that it was strong enough to actually drive it nor the absence of security interests. For instance, in regard to the military operations in Bosnia and Herzegovina $(\mathrm{BiH})$ and Chad, Pohl does offer examples such as the electoral interests in France and the suggestion that intervention occurred due to the "need to do something" in face of mediatized crisis (Pohl 2014, p. 146). Referring to the Darfur crisis and French presidential elections, Pohl argues that " $[t]$ he plight of Darfur had indeed figured prominently in the French presidential election campaign preceding the initiative", considering that "[w]ell-known media personalities had highlighted this conflict and, as several interviewees stressed, their advocacy was perceived by politicians as pressure resulting from public opinion" (Pohl 2014, p. 146). This kind of dynamics were reflected in a promise made by all presidential candidates in 2007, in which they pledged to "mandate the French forces garrisoned in Chad and the Central African Republic to effectively protect the refugees, displaced persons, and members of humanitarian organizations who operate in these countries (...) to make possible a European action to protect the civilian population of Darfur, notably to put into place humanitarian corridors" (Pohl 2014, pp. 146-147). According to Pohl this sort of discourse created expectations about the policy of the incoming administration, not only in regard to Nicolas Sarkozy but also to his future Minister of Foreign and European Affairs, Bernard Kouchner, someone who was expected to advance a humanitarian agenda (Pohl 2017, p. 147). However, this does not seem to constitute valid evidence that those European countries deployed military operations due to public pressure or to obtain public sympathy in a context of contestation.

If Paris had opted for non-intervention there is insufficient evidence to conclude that the French electorate would have pushed leaders out of power for ignoring a humanitarian pledge or even have determinately affected the following elections. The French and most of other Western publics might had been sensitive to the humanitarian plight of Darfur and similar conflicts, as well as in voicing their discontentment about how France and the international community were dealing with the issue (BBC News 2007; Hamilton 2011). Notwithstanding, that does not imply that European citizens were willing to sacrifice their livelihoods - financing operations and sending their youth to a violent foreign battlefield - in order to manage a conflict unrelated to their primordial interests nor, most important to our case, to punish governments that did not deploy such operation. Even if there are cases of leaders seeking to attract public sympathy, rather than being pushed by it to intervene, normative concerns were not the drivers. 
For example, François Hollande's boosting of intervention in Mali is a case in point, considering the domestic difficulties he was facing. There were claims that Holland's policy on Mali was influenced by his attempt to sway public opinion away from domestic problems, especially economic ones (The Economist 2013). However, the selection of Mali seems more understandable when we realize that France has been relevantly exposed to that conflict due to the presence, among the insurgents, of extremist groups such as Al-Qaeda in the Islamic Maghreb (AQIM) as well as due to concerns with a refugee crisis that might spread beyond neighbors such as Burkina Faso and actually increase migratory pressures on France (Welsh 2013; Wagner 2018).

In this context, unfortunately, norms do not seem to be sufficient nor necessary conditions for conflict management to occur. I offer an alternative explanation of realist nature, with power playing the preponderant causal role in a system that is anarchical in nature and prone to competition (see Schweller 2003, p. 323). I suggest that conflict managers are interested primarily in improving their own security and use military operations as a tool of stabilization whenever they are deemed profitable, the result of a cost-benefit calculation that is determined by driving factors. The argument is that those factors are power distribution and exposure, whose combination tends to determine the level of conflict management regardless other factors that may have an intervening effect but not a determinant driving impact. For instance, factors such as the nature of political regimes, economic interdependence among conflict managers, or economic conjunctures may have an effect in decision-making but states do not manage foreign conflicts just because they are democracies, share a single market and a common currency, or there is an economic boom. On the other hand, the distribution of power capabilities and the degree of exposure to externalities generate, per se, incentives that affect the deployment of conflict management operations. To be precise, higher concentrations of power and higher levels of exposure to externalities tend to create stronger degrees of conflict management. In the presence of the same incentives at those two levels, states tend to behave similarly, even if nuances may occur due to intervening conditions.

Power distribution is the first driver because powerful states tend to replicate the domestic conditions of hierarchy in the parcels of the international system that they dominate, an attempt to build up an international hegemonic order that tames anarchy in their favour. Higher concentrations of power generate more incentives for conflict management whereas lower ones are less propitious because the existence of more preponderant third parties leads to competitive deadlocks and there is less amount of resources available to manage conflicts. Nonetheless, the power of preponderant states is not infinite, and they end up selecting the conflicts in which they intervene. Given that such selection is not based on power distribution, 
I consider that a second driver exists, following a multi-causal realist logic in which driving power conditions are complemented by other factors as in the case of Stephen Walt's balance of threat theory, which suggests that balancing is driven by a perception of threat that results not only from power but also from geographic proximity, offensive capabilities, and offensive intentions (Walt 1987).

I consider that exposure is the second driver of conflict management, determining the selection of conflicts to manage. It adds up to structural incentives by determining potential costs that may directly affect the security of third parties. Even if third parties are not directly involved in the conflicts, their societies, economies, and tactical position may be affected, especially when violence is intense. The social, economic, and tactical vulnerabilities determine the type of costs to which third parties are exposed. Members of the societies of a third party, its economy, and its tactical position can suffer direct costs as a result of those conflicts, particularly when those conflicts are located nearby (e.g., collateral damages such as the shooting down of airplanes or uncontrollable migratory inflows), involving important trade partners (e.g., the slowing or breaking down of supply chains), or refer to disputes that involve a challenger (e.g., a rival state or a terrorist group obtaining advantages). Moreover, the intensity of violence in those conflicts affects the potential gravity of externalities. Hence, exposure is a function of societal vulnerability, economic vulnerability, and tactical vulnerability - relational indicators - that determine the type of potential costs that may affect third parties, conjugated with intensity of violence - an indicator exogenous to the relation between third parties and the country in conflict - that determines the potential severity of those costs. The existence of more types and more severe potential costs creates more incentives for conflict management.

Applying the theory to the case of the EU, it is suggested that France, the UK, and Germany (the EU3) used military operations of conflict management under the ESDP and CSDP in order to promote their own security, as a function of power distribution and exposure. To be precise, the first incentive was the partial disengagement of the US from Southeast Europe and Africa, pushing EU members to manage conflicts in a broader context of "reformed bandwagoning", with member-states seeking to promote their own security in an autonomous manner without challenging American predominance (Dyson 2010, pp. 102-106; Dyson 2013, p. 387; Dyson and Konstadinides 2013, pp. 143-154). The second incentive refers to European societal, economic, and tactical vulnerabilities to conflicts in those regions, combined with peaks of violence generated by those conflicts. Members of the EU were driven to address conflicts in countries that were closer, relevant economic partners, and whose governments were fighting enemies or rivals of the EU, especially those that involved dynamics of violence that multiplied the potential costs associated with those vulnerabilities. 
The normative hypothesis would be validated if the EU deployed military operations to manage conflicts that were particularly violent and to which they were not especially vulnerable at geographic, economic, and tactical levels. That would be particularly evident if the EU managed those conflicts in detriment of conflicts that were less violent but to which Europeans were more vulnerable. In order to empirically support my hypothesis, I examine dyadic relations between the EU3 and the intervened states. Altogether, more powerful and exposed states are expected to be more involved in conflict management, seeking to expand their influence in the regions of intervention and to contain the potential costs associated with the sub-indicators of exposure. Interventions are expected to occur in conflicting states that are not only weaker but also a source of exposure to the EU3. Given the limited access to governmental and diplomatic documentation related to military operations, I infer the motivations of French, British, and German governments by combining power and exposure data with the mandates of those operations. In the end, empirical evidence is more supportive of my realist hypothesis rather than the normative one.

Power distribution is parsimoniously operationalized as the allocation of capabilities at the level of nuclear warheads, military expenditure, and nominal GDP, since I consider them to reflect the ability of states to coerce and woo others through punishment and rewards. Asforexposure, the foursub-indicators areoperationalized as follows. Firstly, societal vulnerability is inferred from the geographical distance and obstacles between the third parties and the countries in conflict, based on data from the Center of Geographical Analysis (2020). Lesser distance and fewer obstacles imply a higher probability of societies in third parties being affected by issues such as military collateral damages, human trafficking, and migrant crises. Secondly, economic vulnerability is inferred from the position occupied by conflicting countries in the rankings of raw material imports by third parties, according to the data from the World Trade Integrated Solution of the World Bank (2020b). A higher position in the ranking implies a higher degree of economic vulnerability of the third party. Thirdly, I infer the level of tactical vulnerability of third parties from the presence of challengers, at most already involved in a direct military dispute with the third party (such as the EU in regard to the Islamic State in Syria) or at least competing for the same goods in the international system (as the EU and Russia in respect to political influence over Ukraine). The higher the number of challengers, the higher the level of tactical vulnerability, considering that they are likely to improve their overall position in case of victory in the conflict. I identify the existence or absence of challengers by looking at data from the Uppsala Conflict Data Program-UCDP (2020). Fourth and last, violence intensity is assessed through the ranking of magnitude of societal-systemic impact of the dataset Major Episodes of Political Violence (MEPV) by the Center for Systemic Peace - CSP (2020). 


\section{Background}

Until the emergence of the ESDP in 1999 there was no institutional framework of military cooperation, which until then occurred outside the process of European integration. After the failure of the European Defence Community in 1954, military cooperation between the members of the project of European integration occurred outside that institutional framework, namely through the Western European Union (WEU), Finabel, and the Organisation for Joint Armament Cooperation, along with partner regional organisations of defence and security nature, namely the North Atlantic Treaty Organization (NATO) and the Organization for Security and Co-operation in Europe (Howorth 2007; Gowan and Batmanglich 2010; Dyson 2010, pp. 60-66; Dyson and Konstadinides 2013, pp. 7-34). The establishment of the CSDP in 2009 consolidated EU's process of military cooperation, improving the ability of the EU to deploy military forces in order to promote its interests in a mode compatible with the interests of the US. It has been in this institutional framework that EU's 12 military operations and single civ-mil operation have been deployed in Europe and in Africa. From 2003 onwards the EU has been militarily active in the Balkans and in the whole African continent, through both land and maritime operations, often in combination with civilian operations, such as EUCAP Nestor/Somalia and EUCAP Sahel Mali (EEAS 2020). On 17 February 2020, High Representative/Vice President Josep Borrell announced the decision to launch another naval operation with the intention to enforce the UN arms embargo against Libya - Operation EU Active Surveillance (Rankin 2020).

Table 1 - Military and Civ-Mil Operations of the European Union

\begin{tabular}{|c|c|c|c|c|c|}
\hline OPERATIONS & LOCATION & TYPE & LAUNCHED & $\begin{array}{c}\text { ABSOLUTE } \\
\text { RECRDED } \\
\text { MAX } \\
\text { PERSONNEL }\end{array}$ & STATUS \\
\hline EUFOR Concordia & FYROM & Military & 2003 & 700 & $\begin{array}{c}\text { Concluded in } \\
2003\end{array}$ \\
\hline Artemis & RD Congo & Military & 2003 & 1,807 & $\begin{array}{c}\text { Concluded in } \\
2003\end{array}$ \\
\hline EUFOR Althea & $\begin{array}{c}\text { Bosnia and } \\
\text { Herzegovina }\end{array}$ & Military & 2004 & 7,000 & \begin{tabular}{c} 
Ongoing \\
\hline EU Support to AMIS
\end{tabular} \\
\hline Sudan & Civ-Mil & 2005 & 50 & $\begin{array}{c}\text { Concluded in } \\
2007\end{array}$ \\
\hline EUFOR RD Congo & RD Congo & Military & 2006 & 2,259 & $\begin{array}{c}\text { Concluded in } \\
2006\end{array}$ \\
\hline EUFOR Chad/RCA & Chad/RCA & Military & 2008 & 3,300 & $\begin{array}{c}\text { Concluded in } \\
2009\end{array}$ \\
\hline
\end{tabular}

(Continua) 
The European Union, Conflict Management, and the Normative Illusion

\begin{tabular}{|c|c|l|c|c|c|}
\hline OPERATIONS & LOCATION & TYPE & LAUNCHED & $\begin{array}{c}\text { ABSOLUTE } \\
\text { RECORDD } \\
\text { MAX } \\
\text { PERSONNEL }\end{array}$ & STATUS \\
\hline $\begin{array}{c}\text { EU NAVFOR } \\
\text { Atalanta }\end{array}$ & Somalia & Military & 2008 & 1,943 & Ongoing \\
\hline EUTM Somalia & Somalia & Military & 2010 & 125 & Ongoing \\
\hline EUTM Mali & Mali & Military & 2013 & 570 & Ongoing \\
\hline EUFOR RCA & CAR & Military & 2014 & 700 & $\begin{array}{c}\text { Concluded in } \\
2015\end{array}$ \\
\hline EUMAM RCA & CAR & Military & 2015 & 70 & $\begin{array}{c}\text { Concluded in } \\
2016\end{array}$ \\
\hline EU NAVFOR \\
Sophia
\end{tabular}

Sources: EEAS (2020) and Mauro, Krotz, and Wright (2019).

Some suggest that those military operations were "shallow and safe", "incoherent and contradicting", conditioned by national European interests "primarily French and British", and "divorced from broader security challenges of the region" (Sepos 2013, p. 274; cf. Bailes 2008, pp. 115-130; Styan 2012, pp. 651-668; Olsen 2009, pp. 245-260). Even taking a less assertive stance, it is unanimously recognized that EU operations "were limited to the lower end of the spectrum of military tasks" (Giegerich 2015, p. 454), that "indecisiveness and contradiction" (Giegerich 2015, p. 458) meant that there was no EU intervention in conflicts as crucial as the Libyan one, and that problematic decision-making led to cases such as EUTM Mali, in which the EU "decided to launch its military training mission on the back of the French-led intervention" (Giegerich 2015, p. 458). However, EU military operations are relevant because the organization became the most prolific conflict manager, currently deploying 16 operations, in comparison with 13 by the UN (EEAS 2020; UN 2019), and due to the fact that EU operations played an essential stabilizing role in several occasions, as illustrated by the words of Colonel Pierre Augustin, French representative in Operation Concordia, suggesting that the EU force (EUFOR) had become "a federating security element in the daily life of the ethnic communities" (Rodt and Wolff 2012, p. 144).

\section{Power Distribution}

The first driver of conflict management by the EU was initiated by the collapse of the Soviet Union and the emergence of a unipolar system. According to my criteria, the shift from bipolarity to unipolarity was due especially to a sudden gap between the 
US and Russia at the level of military expenditure, given the visible decline from the 318.8 billion USD spent by the Soviet Union in 1989 to Russia's 57.6 billion USD in 1992 and 29.6 billion USD in 1996, compared to the 580.7, 514.8, and 409.6 billion USD spent by the US during those years (SIPRI 2020). American and Russian nuclear capabilities remained strategically equivalent whereas the advantage of the US in terms of GDP already existed before the end of the Cold War. For instance, the GDP of the Soviet Union in 1989 was 620 billion USD, not comparable with the American GDP of 5.7 trillion USD, not to mention the Japanese GDP of 3.1 trillion USD and even the West German's 1.3 trillion USD (World Bank 2020a). The Soviet Union was a pole due to its nuclear weapons and conventional forces, reflected in its military expenditure, whose decline dealt a fundamental blow in Moscow's power capabilities.

Table 2 - Number of Nuclear Warheads

\begin{tabular}{|lr|c|c|c|c|c|}
\hline & \\
&
\end{tabular}

Unit: Deployed and stockpiled strategic warheads, excluding retired warheads in storage for dismantlement. Sources: Kristensen and Norris (2013, p. 78), Kristensen and Norris (2014, p. 2) and SIPRI (2016, p. 23).

What made the US a unipole was the combination of its nuclear capabilities with its preponderance in terms of military expenditure and nominal GDP. For example, aside from its nuclear preponderance shared with Russia, in 1991 the US shares of global military expenditure and GDP corresponded to outstanding 35 and 25 percent, respectively (SIPRI 2020; World Bank 2020a). That preponderance has continued to exist, as illustrated by the 2015 shares of 33 percent of global military 
expenditure and 24 percent global GDP (SIPRI 2020; World Bank 2020a). Military expenditure reflected American superiority in terms of conventional forces, combined with an extensive network of military bases and an overwhelming presence in the seas, air, and space. On the economic side, Washington could change the behavior of states who wished to profit from American aid, investments and market.

Table 3 - Military Expenditure

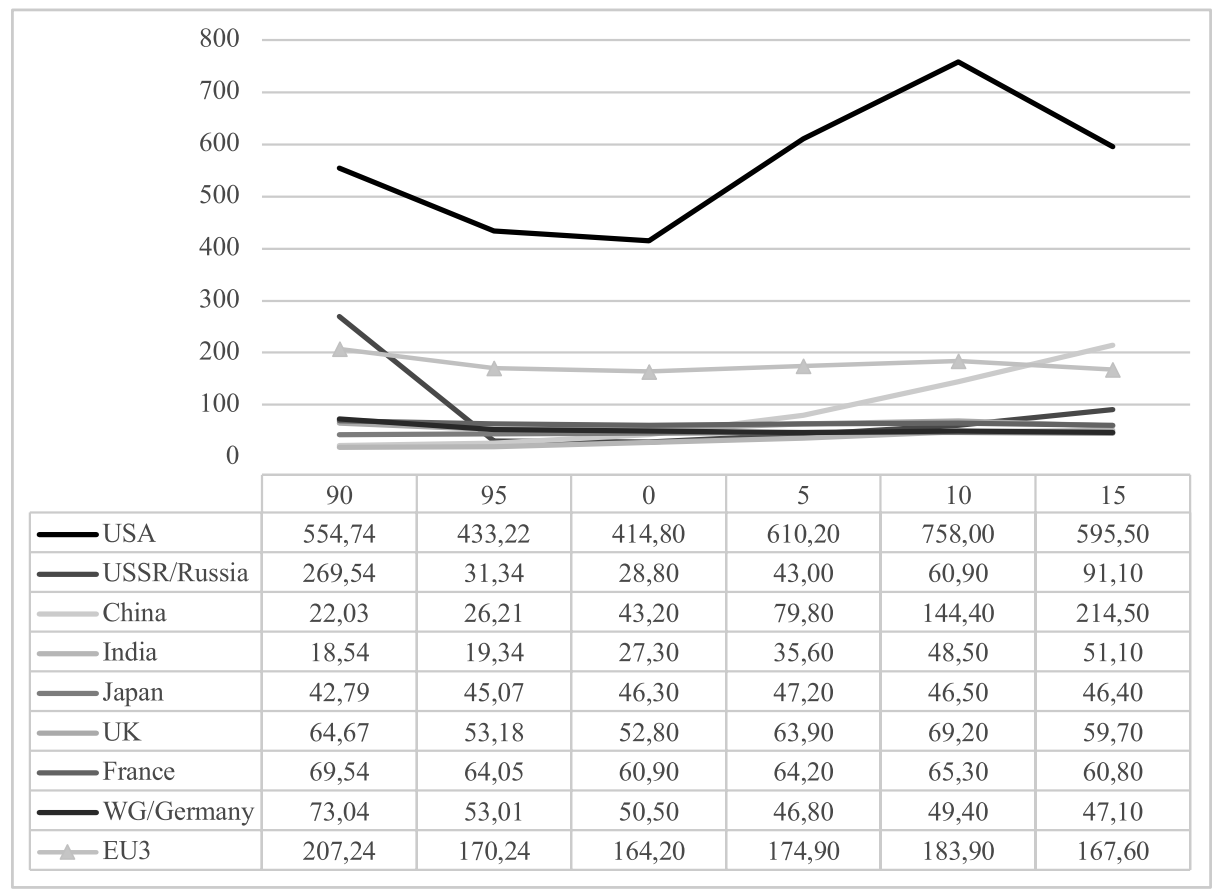

Unit: Billion constant 2014 USD.

Source: SIPRI (2020).

This structural shift had immediate implications for EU members. The Soviet collapse meant that the EU was living what seemed to be the safest security scenario for decades in terms of territorial defence (Posen 2006, pp. 183-184), but at the same time the behaviour of the US was less constrained and there was a refocus on security concerns that were less acute or perceived as such during the Cold War - such as WMD proliferation and smuggling, states collapsing due to the radical politicization of ethnic divisions, globalized terrorist networks, and environmental degradation (Cirincione, Wolfsthal, and Rajkumar 2005; Zaitseva and Hand 2003, pp. 822-844; Kaufman 2001; Cronin 2002/03; Levy 1995). In this context, unipolarity generated a paradoxical anxiety about American hegemonic domination and abandonment. 
On the one hand the power of the US was unchecked by any other state and on the other hand Washington had less incentives to extend a security blanket to its European allies, who still had to deal with Russia and were also facing novel security challenges (cf. Smith 2005, pp. 137-139). This was a period of uncertainty where the US was calibrating its foreign policy and still in the process of identifying the regions that should constitute a military priority, as illustrated by initial interventions in scenarios that later were not considered a priority. Somalia's intervention in 1993 was a case in point and, although more gradually, the eventual shift from the 1990s Balkans strategy also reflected such rethinking. In this context, members of the EU were also calibrating their foreign and security policies. As Tommi Koivula notes, due to "the challenges and opportunities brought by the tectonic changes to the existing international order, the post-Cold War years until approximately 2001 were the formative period of the more general discussion on the overall nature of security as well as the tools and approaches of the international community to promote it" (Koivula 2016, pp. 45).

Table 4 - GDP

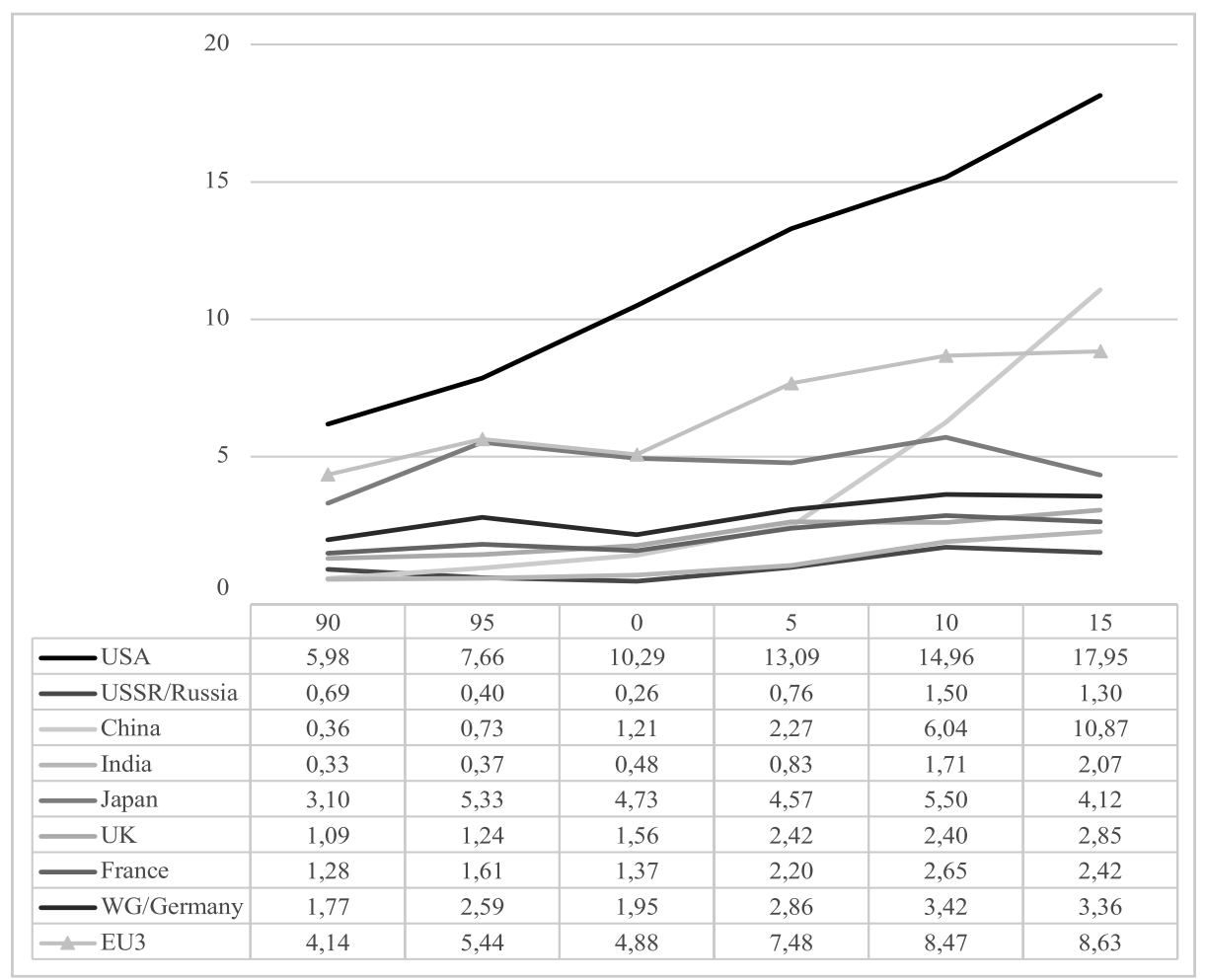

Unit: Trillions of current USD.

Source: World Bank (2020a), "GDP (current US\$)”. 
Under those circumstances, evidence indicates that Europeans used conflict management in a logic of reformed bandwagoning (Dyson 2013), accepting American preponderance but seeking more autonomy to pursue their own interests in a new security environment that involved challenges that were more relevant to Europeans than to the US. On the one hand, although some authors claim that military cooperation in the EU was designed to balance the US (Art 2005 / 2006; Posen 2006; Jones 2007), there was no hard balancing against the US and soft balancing remains an ambiguous concept that does not seem dissociable from normal friction in international politics (Lieber and Alexander 2005). At the same time, although some authors suggest that bandwagoning by the EU, or at least part of its members has occurred (Cladi and Locatelli 2012; Ringsmose 2013), military cooperation is not designed to pursue the interests of the US.

The EU, particularly its three main powers, became a de facto pole in Southeast Europe, a preponderance allowed by the US, whose government was no longer willing to be the main security provider in regions that were not fundamental and whose stability could be pursued by the European allies in a logic of division of labour. The US agreed to keep KFOR in place in Kosovo, but the EU became responsible for the management of other conflicts. In this context, the EU deployed two military operations in the region: Operation Concordia in the FYROM and Operation Althea in $\mathrm{BiH}$. The EU continued to prioritize the stability of the Balkans, pursuing the integration of local countries (Croatia in 2013), negotiating accessions with Serbia, Montenegro, Albania, and FYROM -, and supporting nation-building through stabilization and association agreements and, of course, CSDP operations in $\mathrm{BiH}$ and Kosovo (EEAS 2019a). The adhesion of Albania and Croatia to NATO in 2009, as well as Montenegro later on (NATO 2018), reflected the consolidation of a Transatlantic regional order under which conflict management was exercised. In this context, the EU continued to support peace in $\mathrm{BiH}$ through Operation Althea and, until 2012, Operation EUPM. In a context of high ethno-political tension where it remained unclear whether the challenges were merely political or if there was actually a concrete risk of violence returning (Rodt 2014, pp. 85). Additionally, the EU remained supportive of NATO-led KFOR while continuing to directly focus on the civilian dimension of conflict management through EULEX (EEAS 2018a).

However, the EU did not deploy military operations in countries that were still directly connected to Russia, namely those that remained within Moscow's sphere of influence. This was especially evident in the case of the Ukrainian conflict of 2014. Even if the EU was highly exposed to that conflict due to the geographical proximity of the conflict, energy imports (Pirani and Yafimava 2016, pp. 4-9), and Russia's involvement, it was not possible to intervene due to the military power imbalance between the EU3 and Russia. In 2014 Moscow retained not only a fundamental level of nuclear superiority $-4,300$ Russian warheads vs. 525 Franco-British ones - but 
also a conventional advantage, due to the mismatched capabilities and decentralized political and military chain of command of EU's members, even if at aggregate level the EU3 were enough to outspend Russia in terms of military expenditure - respectively, 168.9 billion USD vs. 84.7 billion USD (SIPRI 2016 and 2020). In a nutshell, due to power distribution, the costs associated with a military intervention in Ukraine by the EU, and even by NATO, were obviously not matched by the benefits. Otherwise, the EU would very likely intervene in the Ukrainian conflict. The end of the Cold War also meant that Africa was no longer a center of dispute between great powers. Russia was in no condition to be an active player in the continent and the US had no interest in serving as pacifier after the failed intervention in Somalia in 1993, as tragically reflected in Washington's inertia during the Rwandan genocide one year later. The power vacuum was partially occupied by the EU through its main powers, especially France and the UK, the former more inclined than the latter to use the EU as a tool of conflict management. As in Southeast Europe, those countries had become de facto poles in the continent, with a degree of structural advantage that offered no doubt about the actors with overwhelming capabilities. For instance, the aggregate military expenditure of all Sub-Saharan African countries in 2001 was 11.9 billion USD while the French expenditure alone was 60.7 billion USD (SIPRI 2020), and the aggregate GDP of Sub-Saharan Africa in the same year was 342.2 billion USD whereas the German one amounted to 1.95 trillion USD (World Bank 2020a). Nonetheless, in practice Europeans were constrained in their capacity to exert joint hegemony in the continent due to their different preferences, the discreet presence of the US, and the structural limitations of those countries in a global system that included Russia and emerging powers such as China. In this context, France, the UK, and Germany had a structural yet limited advantage in Africa, enough to prompt the management of conflict in failed and weak states.

In recent years the political clout of the EU has decreased due to a stronger presence of the US, China, and Russia in Africa. After September 11 the engagement of the US increased due to the presence of terrorist networks, leading not only to the establishment of Camp Lemonnier in Djibouti and the US Africa Command (AFRICOM) in 2007 but also to the establishment of "lily-pad" bases across the continent (Vine 2015, 308-313) and partnerships as the Trans-Saharan Counterterrorism Partnership and the Partnership for Regional East Africa Counterterrorism (US Department of State, 2019). If this strategy of involvement were reversed by Donald Trump, it would imply more autonomy for the EU but less of the crucial American support. This is illustrated by the difficulties faced by the overstretched French military in West Africa (Louet and Diallo 2019), in the context of a potential decision by Trump to decrease the number of American forces in West Africa, which would affect French anti-jihadi operations in countries as Mali, Niger, and Burkina Faso 
(Agence France-Presse 2019). This is particularly important at a time when the preponderance of the US has been challenged by China, a country that has become a gigantic trade and investment partner - consolidated through the Asian Infrastructure Investment Bank and the Belt and Road Initiative (Prinsloo 2019) - keeping a low profile in terms of political conditionality but incrementally promoting what has been coined as "Beijing consensus" (Halper 2010). Additionally, Russia became more active in the African continent (Schmitt and Gibbons-Neff 2020), a strategic return that is part of an increasingly assertive policy, as exemplified by Moscow's policies regarding Ukraine, Syria, Venezuela, and North Korea. Nonetheless, the most powerful members of the EU, especially France, have remained relevant actors in the continent and continued to be structurally incentivized to intervene in the region.

In the end, power distribution in Europe and Africa explains why those countries were incentivized to use the EU as a tool of political influence, but that factor does not tell us much about the selection of conflicts involving weak states, namely in knowing why the EU chose certain conflicts and neglected others. In this sense, one needs to look at exposure to fully understand the deployment of EU military operations.

\section{Exposure to Conflicts}

The normative framework would predict the deployment of military operations in conflicts of highly intense violence, whose dreadful humanitarian consequences would drive European publics to push for interventions or even touch the hearts of EU leaders to an extent that they would spend military resources in taming that violence. On the other hand, my framework suggests that, unfortunately, violence is relevant for decision-making inasmuch as it affects the gravity of potential costs to the security of the EU3, in combination with social, economic, and tactical vulnerability, which determine the type of potential costs. Overall, my framework predicts interventions in weaker states that combine several of the following aspects: geographically close, relevant exporters of raw materials, involved in disputes with actors that oppose the EU, and producing high amounts of violence.

The exposure of the EU was particularly evident in the Balkans. The location of the conflicts and the intensity of violence in $\mathrm{BiH}$ made it essential for the EU to address those conflicts. Allowing such conflicts to continue would thwart the attempt by EU members to expand their influence in the continent and possibly destabilize neighbouring countries due to asylum seekers fleeing from violence, economic migrants running away from misery, and potential criminal networks infiltrated in those populations. The fact that Germany received 1,266,000 refugees in 1995 illustrates EU's exposure to conflicts in that region (World Bank 2019). 
The role of exposure is even more analytically relevant in the case of African continents, considering that the structural clout of the EU is less visible than in the Balkans. The normative hypothesis would suggest interventions based especially in the intensity of violence but Table 5 demonstrates that the EU selected conflicts across the whole spectrum of violence and left extremely violent conflicts unaddressed (such as the Angolan civil war, not to mention the Rwandan genocide of 1994) or virtually unmanaged (as the Sudanese conflict). The scores are attributed according to the impact of violence, which in the case of African conflicts from 1998-2015 ranged from 1 (least violent) to 6 (most violent) (CSP 2020).

Table 5 - Magnitude of Violence per Conflict, 1998-2015

\begin{tabular}{|c|c|c|c|c|c|}
\hline \multicolumn{6}{|c|}{ MEPV Maximum Scores } \\
\hline $\mathbf{1}$ & $\mathbf{2}$ & $\mathbf{3}$ & $\mathbf{4}$ & $\mathbf{5}$ & $\mathbf{6}$ \\
\hline $\begin{array}{c}\text { Ivory Coast } \\
\text { Liberia Cameroon } \\
\text { Mali } \\
\text { Ethiopia }\end{array}$ & $\begin{array}{c}\text { Chad } \\
\text { Uganda } \\
\text { G. Bissau }\end{array}$ & $\begin{array}{c}\text { Nigeria } \\
\text { CAR } \\
\text { Kenya } \\
\text { R. Congo } \\
\text { Senegal } \\
\text { Guinea }\end{array}$ & $\begin{array}{c}\text { Algeria } \\
\text { Burundi } \\
\text { South Sudan } \\
\text { Libya } \\
\text { Rwanda }\end{array}$ & $\begin{array}{c}\text { Ethiopia-Eritrea } \\
\text { Somalia } \\
\text { DRC }\end{array}$ & $\begin{array}{c}\text { Angola } \\
\text { Sudan }\end{array}$ \\
& & & & \\
\hline
\end{tabular}

Sources: CSP (2020).

There was no intervention in all conflicts to which the EU was exposed, either because it involved relatively powerful African countries that were able to manage the conflicts or because the conflicts were being addressed by other organizations. The first type of case is perfectly illustrated by the conflicts in Algeria and Nigeria, two countries that ranked consistently in the top ten exporters of raw materials by the EU3, especially energy related ones (World Bank 2020b), but despite the difficulties ended up being strong enough to address their problems without having to recur to foreign intervention - their military expenditure and GDP are amongst the highest in the continent (SIPRI 2019; World Bank 2020a). For example, Nigeria did require aid and foreign intervention was on the table, but Abuja ended up being strong enough to avoid it. Nigeria has been part of the top 10 African receiving aid countries, but the US had not been deeply involved at military level during that period: "So far, the U.S. military has trained only small numbers of Nigerians to participate in international peacekeeping forces. The U.S. Department of State's budget request for International Military Education and Training (IMET) for Nigeria in fiscal year 2015 is only \$700,000" (Campbell 2014, p. 17; USAID 2019). From its side, the British government of Theresa May has recently signed a partnership with 
the Nigerian president Muhammadu Buhari, committing to train Nigerian forces against Boko Haram and offering know-how on anti-terrorist propaganda (EEAS 2018b; European Commission 2018b). Lastly, the EU has been supporting Nigeria in the conflict against Boko Haram, combining security and development, since the EU has consistently provided aid to Nigeria, supporting a myriad of different projects that include areas as distinct as, for example, energy, gender equality, infrastructures, and desertification (Sabbagh 2018). An overstretched and less exposed US and structurally limited but highly exposed EU3 - plus domestic constraints on the Nigerian government, combined with state structures that still allowed it to control most of the country - seem to explain the lack of an American-European effort to deploy a military operation in Nigeria, even if that possibility was on the table (Campbell 2014, p. 17).

As for the second type of cases, the conflict in Libya was a perfect example, since the EU considered intervention for being highly exposed due to geographical proximity, fuel imports, and the involvement of terrorist organizations, but other organizations ended up stepping in, particularly NATO. Most notably, France and the UK were among the backers of UNSC Resolution 1973 and supported a military intervention in favour of the rebels (UN 2011; Elliott 2011), whereas Germany - which abstained in the voting of that resolution - and Italy were reluctant to promote a military intervention that in general could lead to more instability and, in particular, could have negative political and economic consequences for the governments of Angela Merkel and Silvio Berlusconi. Merkel was still domestically constrained in regard to the use of force and Berlusconi was constrained by politico-economic ties with the regime of Gaddafi, such as the 2008 cooperation and friendship agreement, as well the Libyan share in Italian companies (as FIAT and UniCredit) and the long-term activity of companies like ENI in Libya (Marchi 2017; Herf 2011). Considering that the US and NATO stepped in, countries as France and the UK opted for that institutional framework rather than insisting in the deployment of an EU operation.

As for conflicts with lower levels of exposure, there was no intervention, as in the cases of Uganda, Guinea, and the most recent Burundian conflict. However, the EU certainly paid attention to their evolution as a result of their preponderant position in the continent, putting political pressure on conflicting parties in order to put an end to violence. A case in point was the suspension of aid to Burundi, with EU withholding "direct financial support to Bujumbura after concluding that authorities have not done enough to end conflict" (The Guardian 2016).

In the end, all EU operations in Africa followed the framework's logic. They all addressed conflicts involving states with fragile capabilities and EU security benefited from managing those conflicts due to the exposure of its member states. For example, France "had a strong national interest in using the EU "as an instrument 
to take care of their concerns for the DRC's stability" and its support for EUFOR Thad/RCA "was based primarily on its concern for the stability of two of its key allies in central Africa, Chad and the CAR" (Chafer and Cumming 2010, p. 135). Patrick Berg suggests that the latter operation was about the EU "serving French interests", which was essentially to "stabilise the Chad government whose rule was seriously threatened by ever stronger rebel groups", following the patronage logic of Françafrique (Berg 2009, pp. 57 and 61-62). Even if Europeans were interested in stabilizing the continent, ultimately EU operations were not able to put an end to any of the African conflicts it tried to manage, even if it did alleviate violence in certain regions, as in Bunia, DRC, and successfully tamed particular dimensions of the conflict, as piracy off the coast of Somalia (see Rodt 2014, p. 88; Engberg 2014, pp. 144-151; EEAS 2020). This reflected not only the limitations of European power as well as the fact that EU members were not as exposed to these conflicts as in regard to the one in $\mathrm{BiH}$. We can divide the operations into three broad groups according to the type of exposure.

Firstly, there were early operations that combined the filling of a power vacuum with an attempt to tackle intensive violence that posed political challenges to the European goal of influencing the region. This group includes operations Artemis and EUFOR RD Congo in the Democratic Republic of Congo (DRC), as well as operations EU Support to AMIS and EUFOR Chad/RCA (designed not only to address conflicts in these countries but also to deal with the consequences of the Sudanese conflict). Let us look a bit deeper into the Congolese interventions. Operation Artemis aimed to contribute "to the stabilisation of the security conditions and the improvement of the humanitarian situation in Bunia," in the context of the Ituri conflict in the DRC (EEAS 2017). It was launched on 12 June 2003 - following the Council Decision 2003/432/CFSP of 12 June 2003 and the authorisation granted by the UNSC Resolution 1484 of 30 May - and was concluded on 1 September 2003, transferring authority to the United Nations Organisation Mission in the Democratic Republic of the Congo (MONUC), later known as United Nations Organization Stabilization Mission in the Democratic Republic of the Congo (MONUSCO). The EUFOR RD Congo represented the return of the EU to the country, this time with a military operation designed to support of the MONUC during the delicate and potentially unstable electoral process of July 2006, launched after the UNSC Resolution 1671 of 25 of April authorised it and was concluded on 30 November of the same year (EEAS 2016). The Congolese conflict was not the one to which the EU3 were most exposed to but ended up being strategically relevant to intervene in the DRC due to the combination of a high level of violence with structural incentives, along with the interest of Germany in the prudent and incremental normalization of its use of force in face of domestic skepticism (Bordonaro 2006). Additionally, there were also specific economic interests directly related to the country. The EU3 were not 
economically vulnerable to the conflict in DRC if we refer only to the total trade volume of raw materials but French, British, and German companies were certainly importing valuable goods such as coltan, cassiterite, and wolframite, which later became limited by Brussels precisely due to their connection with conflicts - hence the term "blood minerals" (Barbière 2016; World Bank 2020b; Montague 2002; Koning 2011).

Secondly, there have been maritime operations securing the circulation of maritime lanes essential to EU's economy and dealing with the influx of migrants, namely operations Atalanta and Sophia. Operation NAVFOR Atalanta was launched on 8 December 2008 under the EU Council Joint Action 851, with the goals of protecting vessels of the World Food Programme (WFP), African Union Mission in Somalia (AMISOM) and other vulnerable shipping; deterring and disrupting piracy and armed robbery at sea; monitoring fishing activities off the coast of Somalia; and supporting other EU missions and international organisations working to promote maritime security and capacity in that region (EEAS 2019c). That area was essential due to important sea lanes, "reflected in the considerable military presence, from the Suez canal, via the Red Sea, to the Gulf of Aden" (Engberg 2014, p. 145). In the end the mandate of the mission emphasized both normative and material interests. As Sven Biscop points out, “EU's anti-piracy operation, Atalanta, e.g. was always publicly motivated by a desire to assist the people of Somalia - a laudable purpose of course - while referring to the protection of European trade initially was "not done", as if the one excludes the other" (Biscop 2013, 7). To be precise, the EU was economically motivated due to the amount of imports and exports that crossed those waters, as recognized by the organisation itself: "[w]ith up to $95 \%$ of EU Member States' trade (by volume) transported by sea and $20 \%$ of global trade passing through the Gulf of Aden, EU NAVFOR gives considerable effort to safeguarding trade through this strategic area" (EEAS 2019b). At the end of the period in hand terrorist organizations became major players in the Somali conflict increasing the exposure of the EU - and anti-piracy activities became connected to anti-terrorist ones (Singh and Bedi 2016).

Operation NAVFOR Sophia was established in April 2015 with the main goal of tackling the activity of smugglers and traffickers, especially those involved in the illegal transportation of asylum seekers and migrants from Africa and the Middle East to Europe via the Mediterranean Sea, simultaneously preventing criminal activities and human tragedies such as capsized vessels (EEAS 2019c). Libya is precisely the non-European state most related to this mission, given that the mandate includes cooperation with the Libyan navy, an understandable option due to the fact that this unstable country and the Central Mediterranean continue to be the most active migratory route - from the total of 3,283 registered deaths of migrants trying to cross the Mediterranean in 2016, 3,165 perished in the Central Mediterranean 
(Missing Migrants Project 2018) - an evident source of concern for the EU and its Frontex agency, which has deployed Poseidon Sea Operation and Operation Triton to address some of those issues (Bevilacqua 2017, pp. 165-169). As a result of its geographic proximity to conflicts in the Mediterranean area, the EU was required to patrol an area that witnessed dramatic cases of people risking their lives in highly unsafe travelling conditions. As noted by Giorgia Bevilacqua, "Operation Sophia is often turned into a salvage mission (...), as of 31 December 2015, military forces have completed the rescue of more than 8336 persons, initiated both by detection of boats in distress by military assets or by request from the Rescue Coordination Centre in Rome" and "in 2016, the Operation is often turned into a rescue mission that saved hundreds of migrants at sea while they were attempting the Central Mediterranean route to Europe" (Bevilacqua 2017, p. 178). Last March, the Italian government, through the voice of Vice-Minister Matteo Salvini, forced the end of this Operation Sophia's ship patrols so that the country stops being the main disembarkation point for migrants rescued by those patrols (Euractiv.com with Reuters 2019).

Thirdly, there have been operations designed primarily to tackle Islamic terrorism: EUTM Somalia, EUTM Mali, EUFOR RCA, EUMAM RCA and EUTM RCA. Operation EUTM Mali perfectly illustrates this type of mission. This operation was established on 18 February 2013 with the non-combat mandate of supporting the armed forces of the Malian government (EEAS 2019e). Bamako has been involved since 2012 in a conflict that was originally centered on the Tuareg secessionist quest of the National Movement for the Liberation of Azawad but which ended up being taken over by Islamist movements seeking to control part of the Malian territory, namely Ansar Dine, Ansar al-Sharia, Al Mourabitoun, Macina Liberation Front, Boko Haram, AQIM, and Nusrat Al-Islam (Stratfor 2012; Counter Extremism Project 2018a and 2018b; Roux 2019; CSIS 2019). This meant that the EU3 were relevantly exposed to this conflict at tactical level, a concern later reflected in EU's Strategy for Security and Development in the Sahel (EU 2016b). Moreover, the EU was also exposed due to the inflow of Malians fleeing the conflict and the spreading of the conflict to uranium-rich Niger, a context of social and economic vulnerability that affected France in particular (Wagner 2018; Bolis 2013). The deployment of the EUTM Mali has been done in cooperation with ECOWAS' AFISMA, the G5 Sahel, as well as with the French operations Serval and Barkhane. The operation was later complemented by the civilian Operation EUCAP Sahel Mali, launched in 2014, and was related with to the civilian Operation EUCAP Sahel Niger, launched in 2012, which was located in a pivotal position in relation to Mali, Chad, Nigeria, and Libya - four countries plagued by conflicts with security implications for the EU (EEAS 2019a, 2019b). 


\section{Conclusion}

In anarchical systems dominated by states with preponderant capabilities and where at least one conflict is occurring, the level of conflict management seems to be driven by conditions of power distribution and exposure of preponderant third parties to externalities from conflicts, rather than socially appropriate behaviour. Sadly, as much as we like to imagine the EU as a normative beacon that is willing to spend military resources for moral reasons, evidence indicates that social appropriateness is not driving the use of military resources in the noble task of conflict management. Whether the lives of local populations end up being benefited or not, the driving logic of Europeans seems to remain one of national security.

Both cases of intervention and non-intervention offer us evidence that power distribution and exposure have been fundamental drivers of conflict management under the CSDP. Normative concerns about violence have not per se prompted interventions. The EU has managed conflicts that involved weak states and relevant levels of exposure, whereas conflicts involving stronger states and lower levels of exposure continued unaddressed.

Assuming that the recent trends of power distribution and exposure will not suffer relevant changes, I suggest that conflict management by the EU is likely to decrease due to the shrinking of its relative power. The relative power of EU's main states has been decreasing in the last decade due to the rise of the least developed world, particularly China. Brexit contributes even more for the relative structural decline of the $\mathrm{EU}$, considering the weight of the British economy in the EU - the British GDP in 2017 accounted for 15.2 percent of the aggregate EU GDP (European Commission 2020) - although one may argue that military cooperation between the UK and its former peers may persist through NATO, bilaterally, or through an EU-UK agreement. The relative position of the EU has also grown weaker in Africa due to the increasingly stronger presences of China and, perhaps, Russia, though Europeans will continue to compete for influence in the continent. For instance, the former President of the EU Commission, Jean-Claude Juncker, demonstrated European concern by developing a plan to bolster EU's position in Africa in face of an increasingly influential China, actually trying to become more pragmatic and less focused on political criteria, precisely the method used by Beijing in the continent (European Commission 2018a; Harding 2018).

In this context it is predictable that the EU will deploy less operations, which is not a surprise, considering the absent launchings from 2016 up to the agreement to launching Operation EU Active Surveillance in February 2020. The EU will likely continue to ensure stability in the Balkans and to address essential conflicts in Africa, especially those related to Islamic terrorism and to large scale migratory flows. Despite the difficulties surrounding Operation Sophia, naval operations will 
likely remain essential in securing trade routes, weakening of terrorist networks, and tackling human and arms smuggling, as illustrated by the new EU operation. Hopefully, conflict management by the EU will continue to contribute, as much as possible, to the stabilization of neighboring regions and to improve the livelihood of those affected by violence. Nonetheless, one should be aware that what drives the deployment of those stabilizing forces is not a sense of normative imperative. Regardless of their moral intentions, political leaders in the EU have deployed operations of conflict management to serve, first and foremost, the security interests of their states, and there is no evidence that this logic will be substituted by a normative one.

\section{References}

Agence France-Presse, 2019. Report: US Considers Pulling Troops from West Africa, December 24. Available at: https://www.voanews.com/usa/report-us-considers-pulling-troops-west-africa

Art, R. J., 2005/06. Striking the Balance. International Security, 30, no. 3, pp. 177-185.

Bailes, A. J. K., 2008. The EU and a 'better world': what role for the European security and defence policy? International Affairs, 84, no. 1, pp. 115-130.

BBC News, 2007. Worldwide rallies held for Darfur, September 16. Available at: http: / / news. bbc.co.uk/2/hi/africa/6997327.stm

Berg, P., 2009. EUFOR Tchad/RCA: The EU Serving French Interests, in M. Asseburg and R. Kempin, eds., The EU as a Strategic Actor in the Realm of Security and Defence? A Systematic Assessment of ESDP Missions and Operations. Berlin: SWP Research Paper, pp. 57-69.

Bevilacqua, G., 2017. Exploring the Ambiguity of Operation Sophia Between Military and Search and Rescue Activities, in G. Andreone, ed., The Future of the Law of the Sea: Bridging Gaps Between National, Individual and Common Interests. Cham: Springer Open, pp. 165-189.

Biscop, S., 2013. Europe and the World or Snow White and the Seven Fallacies, Egmont Paper 61.

Bolis, A., 2013. Mines d'uranium : “la France n'a pas intérêt à ce que le conflit malien s'étende au Niger, Le Monde, January 30. Available at: https://www.lemonde.fr/afrique/article/2013/01/30/ mines-d-uranium-la-france-n-a-pas-interet-a-ce-que-le-conflit-maliens-etende-au-niger_1825026_3212.html

Bordonaro, F., 2006. German-led DRC mission sparks controversy. International Relations and Security Network, April 12. Available at: https://reliefweb.int/report/democratic-republic-congo/german-led-drc-mission-sparks-controversy

Campbell, J., 2014. U.S. Policy to Counter Nigeria's Boko Haram, Council Special Report No. 70, CFR. 
Center for Strategic and International Studies (CSIS), 2019. Jama'at Nasr al-Islam wal Muslimin (JNIM). TNT Terrorism Backgrounder, Accessed 21 March 2019, Available at: https: / / www.csis.org/ programs / transnational-threats-project/ terrorism-backgrounders/jamaat-nasr-al-islam-wal-muslimin

Center for Systemic Peace, 2020. Major Episodes of Political Violence. Available at: http:/ / www. systemicpeace.org/warlist/warlist.htm

Center of Geographical Analysis, 2020. WorldMap. Harvard University. Available at: http:/ / worldmap.harvard.edu/

Chafer, T. and G. Cumming, 2010. Beyond Fashoda: Anglo-French security cooperation in Africa since Saint-Malo, International Affairs, 86, no. 5 pp. 1129-1147.

Cirincione, J., J. B. Wolfsthal and M. Rajkumar, 2005. Deadly Arsenals: Nuclear, Biological, and Chemical Threats. Washington: The Brookings Institution Press.

Cladi, L. and A. Locatelli, 2012. Bandwagoning, Not Balancing: Why Europe Confounds Realism, Contemporary Security Policy, 33, no. 2 pp. 264-288.

Counter Extremism Project, 2018a. Al-Mourabitoun. Accessed November 9, Available at: https: / / www.counterextremism.com/threat/al-mourabitoun

Counter Extremism Project, 2018b. Ansar al-Sharia in Libya (ASL). Accessed November 10, Available at: https: / www.counterextremism.com/threat/ansar-al-sharia-libya-asl

Cronin, A. K., 2002 / 03. Behind the Curve: Globalization and International Terrorism, International Security, 27, no. 3, pp. 30-58.

Dyson, T. and T. Konstadinides, 2013. European Defence Cooperation in EU Law and IR Theory. Basingstoke: Palgrave Macmillan.

Dyson, T., 2013. Balancing Threat, Not Capabilities: European Defence Cooperation as Reformed Bandwagoning. Contemporary Security Policy, 34, no. 2, pp. 387-391.

Dyson, T., 2010. Neoclassical Realism and Defence Reform in Post-Cold War Europe. Basingstoke: Palgrave Macmillan.

Elliott, M., 2011. Viewpoint: How Libya Became a French and British War. Time, 19 March, Available at: http: / / content.time.com/time/ world/article/0,8599,2060412,00.html

Engberg, K., 2014. The EU and Military Operations: A comparative analysis. Abingdon: Routledge.

Euractive.com with Reuters, 2019. EU to end ship patrols in scaled down Operation Sophia. Euractiv.com, March 27. Available at: https://www.euractiv.com/section/justice-homeaffairs/news / eu-to-end-ship-patrols-in-scaled-down-operation-sophia/

European Commission, 2020a. Eurobarometer, 1990 to 1997, Accessed February 18. Available at: http:/ / ec.europa.eu/commfrontoffice/ publicopinion/index.cfm/Survey/index\#p= 1\&yearFrom=1991\&yearTo=1997

European Commission, 2020b. Which Member States have the largest share of EU's GDP? Eurostat, January 9. Available at: https://ec.europa.eu/eurostat/web/products-eurostat-news / - DDN-20180511-1?inheritRedirect=true 
European Commission, 2018a. State of the Union 2018: Towards a new 'Africa - Europe Alliance' to deepen economic relations and boost investment and jobs, September 12, Available at: http:/ / europa.eu/rapid/press-release_IP-18-5702_en.htm

European Commission, 2018b. International Cooperation and Development - Nigeria, Accessed November 14, Available at: https:/ / ec.europa.eu/europeaid/countries/nigeria_en

European External Action Service (EEAS), 2020. Security and Defence. Accessed 5 January, Available at: http:/ / eeas.europa.eu/headquarters/headquarters-homepage/ area/security-and-defence_en

European External Action Service (EEAS), 2019a. Factsheet: EU Engagement in the Western Balkans. Accessed November 28, Available at: https://eeas.europa.eu/headquarters/ headquarters-homepage_en / 29660/Factsheet:\%20EU\%20Engagement $\% 20$ in $\% 20$ the $\% 20$ Western\%20Balkans

European External Action Service (EEAS), 2019b. MSCHOA. EU Navfor Somalia, accessed February 13. Available at: https: / / eunavfor.eu/mschoa/

European External Action Service (EEAS), 2019c. Operation EU Navfor Somalia. June 15. Available at: http: / / eunavfor.eu/mission/

European External Action Service (EEAS), 2019d. EU NAVFOR Med - Operation Sophia. Accessed December 10, Available at: https: / www.operationsophia.eu/

European External Action Service (EEAS), 2019e. EUTM Mali. Accessed November 8, Available at: http: / / eutmmali.eu/

European External Action Service (EEAS), 2018a. About EULEX. Accessed January 23, Available at: https: / / www.eulex-kosovo.eu / ?page=2,60

European External Action Service (EEAS), 2018b. Nigeria: EU investing heavily in security and human development. January 18. Available at: https://eeas.europa.eu/topics/europeaid /38397 / nigeria-eu-investing-heavily-security-and-human-development_en

European External Action Service (EEAS), 2017. Artemis. Accessed November 25, Available at: http: / / www.eeas.europa.eu/archives/csdp/missions-and-operations/artemis-drc/ index_en.htm

European External Action Service (EEAS), 2016. EUFOR RD Congo - Mission Description. November 5, Available at: http://www.eeas.europa.eu/archives/csdp/missions-andoperations/eufor-rd-congo/mission-description/index_en.htm

European Union, 2016a. Shared Vision, Common Action: A Stronger Europe-A Global Strategy for the European Union's Foreign and Security Policy. Brussels.

European Union, 2016b. Strategy for Security and Development in the Sahel. Brussels.

European Union, 2008. Report on the Implementation of the European Security Strategy - Providing Security in a Changing World. Brussels. 
European Union, 2003. A Secure Europe in a Better World: European Security Strategy. Brussels.

Giegerich, B., 2015. Foreign and Security Policy, in Helen Wallace, Mark A. Pollack, and Alasdair R. Young, eds., Policy Making in the European Union. Oxford: Oxford University Press.

Gowan, R. and S. Batmanglich, 2010. Too Many Institutions? European Security Cooperation After the Cold War, in B. D. Jones, S. Forman, and R. Gowan, eds., Cooperating for Peace and Security: Evolving Institutions and Arrangements. Cambridge: Cambridge University Press, pp. 80-97.

Halper, S., 2010. The Beijing Consensus: How China's Authoritarian Model Will Dominate the Twenty-First Century. New York: Basic Books.

Hamilton, R., 2011. Fighting for Darfur: Public Action and the Struggle to Stop Genocide. New York: St. Martin's Press.

Harding, A., 2018. Juncker unveils EU's Africa plan to counter China. BBC News, September 12. Available at: https:// www.bbc.com/news/world-africa- 45496655

Herf, J., 2011. Berlin Ghosts: Why Germany was against the Libya intervention. The New Republic, March. Available at: https:/ / newrepublic.com/article/85702/germany-libya-intervention-qaddafi-merkel

Howorth, J., 2007. Security and Defence Policy in the European Union. Basingstoke: Palgrave Macmillan.

Johnston, A. I., 2008. Social States: China in International Institutions, 1980-2000. Princeton: Princeton University Press.

Jones, S. G., 2007. The Rise of European Security Cooperation. Cambridge: Cambridge University Press.

Kaufman, S. J., 2001. Modern Hatreds: The Symbolic Politics of Ethnic War. Ithaca: Cornell University Press.

Koivula, T., 2016. The European Union and the Use of Military Force: Uncovering the myths. Abingdon: Routledge.

Kristensen H. M. and R. S. Norris, 2014. Worldwide deployments of nuclear weapons, 2014. Bulletin of the Atomic Scientists: Nuclear Notebook, 0, no. 0, pp. 1-13.

Kristensen H. M. and R. S. Norris, 2013. Global nuclear weapons inventories, 1945-2013, Bulletin of the Atomic Scientists: Nuclear Notebook, 69, no. 5, pp. 75-81.

Levy, M. A., 1995. Is the Environment a National Security Issue? International Security, 20, no. 2, pp. 35-62.

Lieber, K. A. and G. Alexander, 2005. Waiting for Balancing: Why the World Is Not Pushing Back, International Security, 30, no. 1, pp. 109-139. 
Louet S. and T. Diallo, "As France mourns 13 soldiers, top general says full victory in Africa impossible", Reuters, November 27, 2019, Available at: https:/ / www.reuters.com/ article / us-france-mali / as-france-mourns-13-soldiers-top-general-says-full-victory-in-africa-impossible-idUSKBN1Y11X4

Manners, I., 2002. Normative Power Europe: A Contradiction in Terms? Journal of Common Market Studies, 40, no. 2, pp. 235-258.

Marchi, L., 2017. The EU in Libya and the collapse of the CSDP. US-China Law Review Journal, 14 , no. 6 .

Mauro, D. di, U. Krotz, and K. Wright, 2019. EU's Global Engagement: A Database of CSDP Military Operations and Civilian Missions Worldwide, Version 2.0, European University Institute, accessed December 1. Available at: http:/ / globalgovernanceprogramme.eui.eu/ eu-global-engagement-database/

Meyer, C. and E. Strickmann, 2011. Solidifying Constructivism: How Material and Ideational Factors Interact in European Defence. Journal of Common Market Studies, 49, no. 1, pp. 6181.

Missing Migrants Project, 2018. Mediterranean. Accessed December 10, Available at: https: / / missingmigrants.iom.int/region/mediterranean

NATO, 2018. NATO on the Map - NATO Members, January 23. Available at: https:/ /www. nato.int $/$ nato-on-the-map / \#lat=51.72673918960763\&lon $=4.849117014409103 \& z o o m=0$

Olsen, G. R., 2009. The EU and military conflict management in Africa: for the good of Africa or Europe? International Peacekeeping, 16, no. 2, pp. 245-260.

Pirani, S. and K. Yafimava, 2016. Russian Gas Transit Across Ukraine Post-2019: pipeline scenarios, gas flow consequences, and regulatory constraints. OIES Paper NG 105, Oxford Institute for Energy Studies.

Pohl, B., 2014. EU Foreign Policy and Crisis Management Operations: Power, purpose and domestic politics. Abingdon: Routledge.

Pohl, B., 2013a. Neither Bandwagoning nor Balancing: Explaining Europe's Security Policy. Contemporary Security Policy, 34, no. 2, pp. 353-373.

Pohl, B., 2013b. The logic underpinning EU crisis management operations. European Security, 22, no. 3, pp. 307-325.

Posen, B. R., 2006. European Union Security and Defense Policy: Response to Unipolarity? Security Studies, 15, no. 2, pp. 149-186.

Rankin, J., 2020. EU agrees to deploy warships to enforce Libya arms embargo", The Guardian, February 17. Available at: https: / / www.theguardian.com/world/2020/feb/17/ euagrees-deploy-warships-enforce-libya-arms-embargo

Ringsmose, J., 2013. Balancing or Bandwagoning? Europe's Many Relations with the United States. Contemporary Security Policy, 34, no. 2, pp. 9-12. 
Rodt, A. P., 2014. The European Union and Military Conflict Management: Defining, evaluating, and achieving success. Abingdon: Routledge.

Rodt, A. P. and S. Wolff, 2012. EU Conflict Management in Bosnia and Herzegovina and Macedonia, in R. Whitman and S. Wolff, eds., The European Union as a Global Conflict Manager. Abingdon: Routledge.

Roux, P. L., 2019. Confronting Central Mali's Extremist Threat, February 12, Africa Center for Strategic Studies. Available at: https://africacenter.org/spotlight/confronting-central-malis-extremist-threat/

Sabbagh, D., 2018. Theresa May signs security partnership with Nigeria's president, The Guardian, August 29. Available at: https://www.theguardian.com/politics/2018/ aug/29/theresa-may-signs-security-partnership-nigeria-president-military-training-fight-boko-haram

Schmitt, E. and T. Gibbons-Neff, 2020. Russia Exerts Growing Influence in Africa, Worrying Many in the West, The New York Times, January 28. Available at: https:/ / www.nytimes. com/2020/01/28/world/africa/russia-africa-troops.html

Schweller, R. L., 2003. The Progressiveness of Neoclassical Realism, in Colin Elman and Miriam Fendius Elman, ed., Progress in International Relations Theory: Appraising the Field. Cambridge, MA: The MIT Press, pp. 323.

Sepos, A., 2013. Imperial power Europe? The EU's relations with the ACP countries. Journal of Political Power, 6, no. 2, pp. 261-287.

Singh, C. and A. S. Bedi, 2016. War on Piracy: The Conflation of Somali Piracy with Terrorism in Discourse, Tactic, and Law. Security Dialogue, 47, no. 5, pp. 440-458.

Smith, M., 2005. Taming the Elephant? The European Union and the management of American power. Perspectives on European Politics and Society, 6, no. 1, pp. 129-154.

Stockholm International Peace Research Institute (SIPRI), 2020. Military Expenditure Database. Accessed January 20. Available at: https: / / www.sipri.org/databases/milex

Stockholm International Peace Research Institute (SIPRI), 2016. Yearbook 2016: Armaments, Disarmament, and International Security - Summary. Stockholm: SIPRI.

Stratfor, 2012. Jihadist Groups Active in Northern Mali. October 2. Available at: https:// worldview.stratfor.com/article/jihadist-groups-active-northern-mali

Styan, D., 2012. EU power and armed humanitarianism in Africa: evaluating ESDP in Chad. Cambridge Review of International Affairs, 25, no. 4, pp. 651-668.

The Economist, 2013. François Hollande's new war trappings. January 19. Available at: https: / / www.economist.com / europe / 2013/01/19/ francois-hollandes-new-war-trappings 
The Guardian, 2016. EU suspends aid to Burundi's government. March 15. Available at: https: / / www.theguardian.com/global-development/2016/mar/15/eu-suspends-aidto-burundi-government

U. S. Department of State, 2019. Programs and Initiatives. Bureau of Counterterrorism and Countering Violent Extremism. Accessed September 22, Available at: https: / / www.state. gov/ bureau-of-counterterrorism-and-countering-violent-extremism-programs-and-initiatives / \#TSCTP

United Nations, 2019. List of Peacekeeping Operations, 1948-2018. Accessed August 13. Available at: https:/ / peacekeeping.un.org/en/where-we-operate

United Nations, 2011. Security Council Approves 'No-Fly Zone' over Libya, Authorizing 'All Necessary Measures' to Protect Civilians, by Vote of 10 in Favour with 5 Abstentions. Meetings Coverage and Press Releases, 17 March. Available at: https:/ / www.un.org/press/ en/2011/sc10200.doc.htm

United States Agency for International Development (USAID), 2019. U.S. Foreign Aid by Country - Nigeria. Accessed October 10, Available at: https://explorer.usaid.gov/cd/ NGA?fiscal_year=2010\&measure=Obligations

Uppsala Conflict Data Program (UCDP), 2020. UCDP. Uppsala Universitet. Accessed January 4, Available at: http:/ / ucdp.uu.se/

Vine, D., 2015. Base Nation: How U.S. Military Bases Abroad Harm America and the World. New York: Metropolitan Books.

Wagner, F., 2018. E.U. Deportations Risk Further Destabilizing Mali. News Deeply - Refugees Deeply, July 2. Available at: https: / www.newsdeeply.com/refugees/community/ 2018/07 / 02 /e-u-deportations-risk-further-destabilizing-mali

Walt, S. M., 1987. Origins of Alliances. Ithaca: Cornell University Press.

Welsh, M. Y. 2013. Making sense of Mali's armed groups. Al-Jazeera, January 17. Available at: https: / / www.aljazeera.com/indepth / features / 2013/01/20131139522812326.html

World Bank, 2020a. GDP (current US\$). Accessed January 3, Available at: https: / / data.worldbank.org/indicator / NY.GDP.MKTP.CD?locations=EU-US-CN

World Bank, 2020b. World Integrated Trade Solution. January 2. Available at: https://wits. worldbank.org/

World Bank, 2019. Refugee population by country or territory of asylum. Accessed September 4, Available at: https:/ / data.worldbank.org/indicator/SM.POP.REFG

Zaitseva, L. and K. Hand, 2003. Nuclear Smuggling Chains: Suppliers, Intermediaries, and End-Users. American Behavioral Scientist, 46, no. 6, pp. 822-844. 